\title{
Crystalline Silica Quartz
}

National Cancer Institute

\section{Source}

National Cancer Institute. Crystalline Silica Quartz. NCI Thesaurus. Code C791.

An industrial material used as an abrasive. It is also formed during cutting, sawing, drilling, and crushing of concrete, brick, block, rock, and stone products. Crystalline silica is classified as a human lung carcinogen and it can also cause silicosis. 